\title{
Test for Identification of Signs of Dyslexia: effects of developmental variables
}

\author{
Rauni Jandé Roama-Alves ${ }^{1}$ \\ Federal University of Rondonópolis, Rondonópolis-MT, Brasil \\ Sofia Pellisson \\ State University of Campinas, Campinas-SP, Brasil \\ Tatiana de Cassia Nakano \\ Pontifical Catholic University of Campinas, Campinas-SP, Brasil \\ Cintia Alves Salgado-Azoni \\ Federal University of Rio Grande do Norte, Natal-RN, Brasil \\ Tatiane Lebre Dias \\ Federal University of Mato Grosso, Cuiabá-MT, Brasil \\ Sylvia Maria Ciasca \\ State University of Campinas, Campinas-SP, Brasil
}

\section{ABSTRACT}

This study aimed to verify the effects of developmental variables as age, school grade and gender in the performance of the Test for Identification of Signs of Dyslexia (TISD). In particular from the analysis of the first two, it was also sought to verify validity evidence based on external variables. Participants were 515 children, randomly selected, ages between six and 13 years old (Average $=8.46 ; S D=1.52)$ and $52 \%$ of males. Through the Univariate Analysis of Variance, only effects of age and school grade were found. It was observed that TISD was able to differentiate groups of six, seven, and eight years old and the school grade of the 1st to 4th grade of elementary school. From these results, it was possible to add positive validity evidence to the instrument, in order to motivate the conduction of other research studies of its psychometric qualities.

Keywords: dyslexia; learning disorders; psychometry; validity; neuropsychology.

\section{RESUMO - Teste para Identificação de Sinais de Dislexia: efeitos de variáveis desenvolvimentais}

Este estudo objetivou verificar efeitos das variáveis desenvolvimentais de idade, ano escolar e gênero no desempenho do Teste para Identificação de Sinais de Dislexia (TISD). Especificamente, a partir da análise das duas primeiras, buscou-se também averiguar evidências de validade desse instrumento baseadas em variáveis externas. Participaram 515 crianças, selecionadas aleatoriamente, com idades entre seis e 13 anos $(M=8,46 ; D P=1,52)$ e $52 \%$ pertencentes ao gênero masculino. Por meio da análise univariada da variância, foram encontrados somente efeitos das variáveis idade e ano escolar. Observou-se que o TISD foi capaz de diferenciar grupos de seis, sete e oito anos e também os anos escolares do primeiro ao quarto ano. A partir desses resultados, foi possível adicionar evidências positivas de validade para o instrumento, de modo a motivar a condução de outros estudos de investigação de suas qualidades psicométricas.

Palavras-chave: dislexia; transtornos de aprendizagem; psicometria; validade; neuropsicologia.

\section{RESUMEN - Prueba de Identificación de Señales de Dislexia: efectos de variables de desarrollo}

Este estudio objetivó comprobar los efectos de las variables del desarrollo de edad, año escolar y género en la ejecución del "Prueba de Identificación de Señales de Dislexia" (TISD). Específicamente a partir del análisis de las dos primeras, se buscó también verificar evidencias de validez de dicho instrumento basadas en variables externas. Participaron 515 niños, seleccionados al azar, con edades comprendidas entre seis y 13 años $(M=8.46 ; D S=1.52)$ y 52\% de hombres. Por medio del Análisis Univariado de Varianza, sólo se encontraron efectos de las variables edad y año escolar. Se observó que el TISD fue capaz de diferenciar grupos de seis, siete y ocho años y también los años escolares del primer hasta el cuarto año. A partir de estos resultados, fue posible añadir evidencias positivas de validez para el instrumento, con la finalidad de motivar la conducción de otros estudios de investigación de sus cualidades psicométricas.

Palabras clave: dislexia; trastornos del aprendizaje; psicometría; validez; neuropsicología.

Developmental Dyslexia (DD) is in the Diagnostic and Statistical Manual of Mental Disorders (DSM-5)
(American Psychological Association [APA], 2013) in the section "Specific Disorder of Learning" and the 
International Classification of Diseases (ICD-10) (World Health Organization [WHO], 1993) under the nomenclature of "Specific Reading Disorder". It affects 5-15\% of school-age children (APA, 2013).

The main diagnosis criteria of this disorder are: (a) continuing difficulties in learning and use of reading ability, being observed reading of words inaccurately or slowly and with struggle; (b) losses on the accuracy of reading words, speed or fluency of reading and reading comprehension; (c) reading ability should be substantially and quantitatively lower than expected for chronological age of the individual, causing significant interference in academic or professional performance or in daily activities; (d) difficulties in learning to read should begin during the school years, but may manifest later, when there is greater demand of this ability that exceeds the limited capabilities of the individual; (e) such difficulties can not be explained by intellectual disabilities, not corrected visual or hearing impairment, other mental or neurological disorders, psycho-social variables, lack of proficiency in academic language instruction or inadequate educational instruction; (f) poor performance in reading on standard measures administered individually (APA, 2013; WHO, 1993).

It is observed that these measures have been routinely prepared by DD researchers and are composed of commonly affected skills in this status, according to theoretical and empirical indications that have been studied in the area. At the international level, for example, an instrument developed by Cox (2002), called the "Test of Dyslexia and Dysgraphia" whose goal is to assist in the identification of DD and Dysgraphia can be found. The assessments that compose the test assess fundamentally phonological skills, visual processing, verbal and symbols memory and symbols rapid naming. Also, there is the "Dyslexia Early Screening Test" (LOC-2) (Fawcett, Nicolson, \& Lee, 2014). It is aimed at education professionals and provides indicative of risk for DD. It consists of rapid naming tasks, phonemic discrimination, visual coordination, postural stability, rhyme, naming of digits and letters, copy of forms, attention, order of sounds and vocabulary.

In the Brazilian context, the "Protocol of Assessment of Cognitive Linguistic Skill (Protocolo de Avaliação de Habilidades Cognitivo-Linguísticas)" - (PAHCL) developed by Capellini and Smythe (2008) based on an adaptation of "International Dyslexia Test" (Smythe \& Everatt, 2000) and the "Protocol for Early Identification of Reading Problems in School of 1st year (Protocolo para Identificação Precoce dos Problemas de Leitura em Escolares do $1^{\circ}$ ano)" (PIPPLE), proposed by Capellini et al. (2009). Both consist of reading assignments of words and pseudo words, phonological awareness, auditory processing and processing speed. Specifically, the PAHCL also evaluates short-term memory skills and visual processing and the PIPPLE, visual attention tasks and understanding of sentences from presented pictures.
There is also the "Screening Protocol for Early Identification of Reading Problems (Protocolo de Triagem para Identificação Precoce de Problemas de Leitura)", developed by Germano, César, and Capellini (2017). It consists of seven subtests which assess reading skills of letters, words and pseudo words, phonological awareness, identification and production of rhymes, phonological memory, rapid naming, auditory comprehension of phrases and images.

The "Test for Identification of Signs of Dyslexia (Teste para Identificação de Sinais de Dislexia)" (TISD), which, classified as a screening tool, was developed based on many Brazilian and international instruments designed specifically to evaluate the DD (Alves, Lima, Salgado-Azoni, Carvalho, \& Ciasca, 2015). It consists of eight subtests involving both academic skills as cognitive, related to written language. The subtests are in particular the following: (1) Reading; (2) Writing; (3) Visual Attention; (4) Calculation; (5) Motor Skills; (6) Phonological awareness; (7) Rapid naming; (8) Shortterm memory.

However, as seen in other Brazilian instruments and on TISD, validity evidence studies are still scarce (Alves et al., 2013). Such studies allow to check "the degree to which evidence theory and support the interpretation of the test scores related to the proposed uses," according to the American Educational Research Association, APA, and the National Council on Measurement in Education (AERA, APA, \& NCME, 2014, p.78). These associations establish what evidence needs to demonstrate a test to be considered valid and may be: (a) evidence-based content; (b) evidence based on response process; (c) evidence based on the testing consequences; (d) evidence based on the internal structure; and (e) evidence based on external variables (AERA, APA, \& NCME, 2014).

To date, TISD had investigated the first and the last type of validity evidence. In a study by Alves et al. (2015), the authors sought to present the process of its construction and also a study of agreement between judges about all instrument structure. Four expert judges were consulted, one of psychology, a neuropsychology and two speech therapy. For virtually all items and materials initially produced, there was a concordance in maintaining items greater than $75 \%$, with only a few items in the subtests of Reading and Writing such value was not found. changes were necessary in the form of evaluation of some words and pseudo words. Subsequently, on further analysis and further modification of those items, concordances were obtained above this value.

In another study, by Alves et al. (2013), TISD performance in a group without learning disabilities $(n=9)$ was compared with another with such difficulties $(n=11)$. The results showed differences between the groups in the scores of Reading, Writing, Mathematics, Phonological awareness, Short Term Memory subtests and Total, with better performance than the group without learning 
disabilities. Statistically significant, moderate and high correlations between TISD and "School Performance Test (Teste de Desempenho Escolar)" (TDE) (Stein, 1994) subtests were also observed (TISD Reading versus TDE Reading: $r=-0.70$; TISD Writing versus TDE Writing: $r=-0.88$; TISD Calculation versus TDE Arithmetic: $r=-0.73$ ). Thus, the authors were able to show initial evidence of validity based on external variables.

Validity studies of this kind can also involve analysis of variable effects linked to human development, such as age and school year. These are classic effects types to be found in the constructs of evaluation that change over time and / or through continuous academic stimulation (AERA, APA, \& NCME, 2014), as written language, ability that is evaluated by TISD.

Gender, in turn, also seems to have an effect on the development of this language as both the oral (Coates, 2015; Voyer \& Voyer, 2014). However, it is not yet possible to find a pattern in the findings. Some research indicates superior results presented for males in both types of language (Flores-Mendoza et al, 2013; Goldbeck, Daseking, Hellwig-Brida, Waldman, \& Petermann, 2010), but others suggest the opposite, for female superiority in these same skills (Lundberg, Larsman, \& Strid, 2012; Wallentin, 2009). There are also those investigations that indicate no significant differences between these two groups (Hyde, 2014; Wechsler et al., 2014; Zell, Krizan, \& Teeter, 2015). This variation of findings has been explained by many variables, such as neurobiological differences,

Thus, this study aimed to verify the effects of variables that mediate the development of cognitive-linguistic skills in the performance of TISD such as age, school year (and type of school, public or private) and gender. Specifically from the analysis of the first two, also sought to ascertain evidence of validity of the instrument based on external variables in a more forceful way. As a hypothesis, it was expected that they all exert impact on the performance of this instrument.

\section{Method}

\section{Participants}

The study included 515 children and adolescents from public schools $(n=403)$ and individuals $(n=112)$. Of these, the majority were males ( $n=268,52 \%)$ of ages 6 to 13 years old (Average $=8.46, S D=1.52$ ) with the following frequency distribution: age $6(n=60)$, age 7 $(n=94)$, age $8(n=102)$, age $9(n=118)$, age $10(n=104)$, age $11(n=27)$, age $12(n=6)$ and age $13(n=4)$. On the other hand, the frequency distribution of school years were: 1 st year $(n=87)$, 2 nd year $(n=93)$, 3 rd year $(n=120)$, 4th year $(n=110)$ and 5 th year $(n=105)$. This sample was obtained in two regions of the country: (1) Southeast (São Paulo and Minas Gerais): 461 subjects; (2) Northeast (Rio Grande do Norte): 54 subjects.
It is emphasized that these participants were selected randomly, the only inclusion criterion that should attend the school years of the first primary education cycle. The exclusion was not understanding some of the instructions of the subtests.

\section{Instrument}

Test for Identification of Signs of Dyslexia (TISD) (Alves et al., 2015). Screening instrument that aims to investigate indicative signs to DD. The test consists of 8 subtests (picture 1) of individual application. The score is calculated based on misses, so that high scores indicate poor performance. The test application lasts approximately 25 minutes.

As for the evidence of the validity already identified, described by Alves et al. (2015) study, four expert judges, one of psychology, a neuropsychology and two speech therapy indicated a concordance in maintaining items greater than $75 \%$. Only a few items of the subtests in reading and writing that value was not found so changes in the way some words and pseudowords were evaluated were made. Subsequently, on further analysis and further modification of those items, concordances were obtained above this value. It can be said that such data indicated evidence based on test content.

In another study, by Alves et al. (2013), TISD performance in a group without learning disabilities $(n=9)$ was compared with that of another with such difficulties $(n=1)$. The results showed differences between the groups in the scores of subtests of Reading, Writing, Mathematics, Phonological awareness, Short Term Memory and Total, with better performance the group without learning disabilities. Statistically significant, moderate and high correlations between TISD and School Performance Test (TDE) (Stein, 1994) subtests were also observed (TISD Reading versus TDE reading: $r=-0.70$; TISD Writing versus TDE Writing: $r=-0.88$; TISD Calculation versus TDE arithmetic: $r=-0.73$ ). Thus, the authors were able to show initial evidence of validity based on external variables.

\section{Procedures}

Initially, an authorization to carry out the research in both the public schools and in particular the states of São Paulo, Minas Gerais, and Rio Grande do Norte were requested. Then the project was approved by the Research Ethics Committee of PUC-Campinas (CAAE: 45679615.7.1001.5481).

All data were collected in the schools of the participants and the following sequence was carried out: (1st) meeting with the parents / guardians; at that time it was presented the research (objectives, methods, results and possible social impacts) and if it was accepted the use of TISD on their children they were asked to sign the free consent form authorizing their child to participate; (2nd) application of TISD in a well lighted and quiet room, 
with an average duration of 25 minutes in one session; for children older than 10 years prior to that procedure was also requested their signature on the Free Consent Form to participate in the research.

\section{Data analysis}

The following tests were used: 1. for comparison of independent groups, univariate analysis of variance (ANOVA); The effect size was verified by Partial Eta Squared $\left(\eta p^{2}\right)$ with the following reference values: values close to 0.01 as small effect; near 0.06 as average effect; close or values greater than 0.14 as great effect (Mertler \& Reinhart, 2016); in order to identify significant differences between each intra-group average values, the post hoc Tukey test was carried out; 2 . to correlate the numerical data, Pearson correlation $(r)$; the reference values adopted for these correlations were: poor correlation values between 0.00 and 0.30 ; moderate correlation values between 0.30 and 0.70 ; Strong correlation values between 0.70 and 1.00 (Cronk, 2017).

It is emphasized that parametric analyzes were used, although the Kolmogorov-Smirnov test for normality, and Levene for homogeneity indicate significance above $p<0.05$. The sample presented a high number of participants, which ensured such use (Foreman \& Corder, 2014).

The significance level was set at $p \leq 0.05$. For all statistical analysis employed IBM Statistical Package for Social Sciences (SPSS) 22.0 for Windows was used.

\begin{tabular}{|l|l|c|}
\hline \multicolumn{1}{|c|}{ Subtest } & \multicolumn{1}{|c|}{ Scored items } & $\begin{array}{c}\text { Maximum score on } \\
\text { each item and total }\end{array}$ \\
\hline $\begin{array}{l}\text { Reading } \\
\text { Recognition of letters, words } \\
\text { and pseudo words reading. }\end{array}$ & $\begin{array}{l}\text { L1 - recognition of 21 letters of the alphabet } \\
\text { L2 - reading of nine words } \\
\text { L3 - reading of nine pseudo }\end{array}$ & $\begin{array}{c}21 \\
09 \\
09 / \text { Total: } 39\end{array}$ \\
\hline $\begin{array}{l}\text { Writing } \\
\text { Writing letters, words and pseudo words. }\end{array}$ & $\begin{array}{l}\text { E1 - dictation of 21 letters of the alphabet } \\
\text { E2 - dictation of nine words } \\
\text { E3 - dictation of nine pseudo }\end{array}$ & $\begin{array}{c}21 \\
09\end{array}$ \\
09 Total: 39
\end{tabular}

Figure 1. TISD Subtests and Their Scores

\section{Results}

Initially, the average and standard deviations of the scores obtained in TISD was calculated. In Table 1 that data can be observed, according to the performance achieved in each age, school year (public and private school) and gender. Regarding to age, it is observed, in general, the score decreases as there is the increase in this variable, except the age of 12 and 13, when in which it notes an increase in the average of the group. As for the school year notes a decrease in scores from year to year, both in public schools and in private. You can also see that the scores of public school are higher in each year, that is to say, there was a worse performance when compared to private schools. Regarding to gender, the averages were very close, despite the girls have gotten a slightly better performance.

It was employed Univariate Analysis of Variance (ANOVA) in order to identify whether there would be effects of these variables on test performance. It also investigated the interaction between them.

The results indicated isolated and significant effect of age and school year, with average magnitudes of effect, although with less effect, 
specifically with small magnitude of effect, type of school as well. There was no isolated effect of gender, as well as interactions between variables, all with small magnitude of effect.

Given the results of ANOVA, the variables that were investigated showed significant by the post hoc Tukey test. This analysis had the objective to identify which groups the differences were statistically significant. The comparisons of TISD's average obtained for each age are shown in Table 3.

The means per school year were also compared. These results can be found in Table 4 .

Table 1

Average and Standard Deviation Obtained in TISD by Age, School Year, School Type and Gender

\begin{tabular}{|c|c|c|c|c|c|c|}
\hline Age & $M(S D)$ & School year & Type & $M(S D)$ & Gender & $M(S D)$ \\
\hline 6 & $66.11(29.86)$ & \multirow{2}{*}{1} & Public & $63.81(33.40)$ & Male & 36.09 (20.30) \\
\hline 7 & 38.45 (15.87) & & Private & $49.92(12.55)$ & Female & 33.89 (21.01) \\
\hline 8 & 31.09 (14.23) & \multirow{2}{*}{2} & Public & 36.11 (13.61) & & \\
\hline 9 & 28.68 (13.61) & & Private & $28.31(10,80)$ & & \\
\hline 10 & $26.70(14,40)$ & \multirow{2}{*}{3} & Public & 36.09 (17.38) & & \\
\hline 11 & $28.40(11.91)$ & & Private & $26.16(6.14)$ & & \\
\hline 12 & $30.66(7.52)$ & \multirow{2}{*}{4} & Public & $26.94(13.21)$ & & \\
\hline 13 & $44.50(22.78)$ & & Private & $25.95(8.44)$ & & \\
\hline & & \multirow{2}{*}{5} & Public & 26.37 (11.77) & & \\
\hline & & & Private & $19.88(4.48)$ & & \\
\hline
\end{tabular}

Note. $\mathrm{M}=$ Mean; $\mathrm{SD}=$ Standard deviation

Table 2

ANOVA for Age, School Year, School Type and Gender in TISD

\begin{tabular}{|c|c|c|c|c|}
\hline \multicolumn{5}{|c|}{ ANOVA (Total TISD) } \\
\hline Variable & Average Square & $F$ & $p$ & $\eta p^{2}$ \\
\hline Age & 1214.979 & 4,564 & $\leq 0.001^{*}$ & 0,065 \\
\hline School year & 1157.391 & 4,348 & $0.002 *$ & 0.036 \\
\hline Type of School & 2126.281 & 7,987 & $0.005^{*}$ & 0.017 \\
\hline Gender & 536.372 & 2,015 & 0.156 & 0.004 \\
\hline Age $x$ School Year & 294.407 & 1,106 & 0.358 & 0.014 \\
\hline Age $x$ Type of School & 590.845 & 2,219 & 0.051 & 0.023 \\
\hline Age $x$ Gender & 318.366 & 1,196 & 0.303 & 0.018 \\
\hline School year $x$ Type of School & 212.729 & 0.799 & 0.526 & 0.007 \\
\hline School year x Gender & 168.339 & 0.632 & 0.640 & 0.005 \\
\hline Type of school x Gender & 56.270 & 0.211 & 0.646 & 0,000 \\
\hline Age x School Year $x$ Type of School & 13,688 & 0.051 & 0.821 & 0,000 \\
\hline Age x Gender x School Year & 449.839 & 1,690 & 0.186 & 0.007 \\
\hline Age x Type of School x Gender & 149.938 & 0.563 & 0.728 & 0.006 \\
\hline School Year $x$ Gender x School Type & 183.128 & 0.688 & 0.601 & 0.006 \\
\hline Age $x$ School Year $x$ Type of School $x$ Gender & - & - & - & - \\
\hline
\end{tabular}

Note. *Significant Value

It was found that the age of 6 differed from almost all other investigated in this study, except for the age of 13. The age 7 did not differentiated only from the ages of 11 , 12 and 13 . The ages of 8,9 , and 10 years differed from the ages of 6 and 7 . The ages of 11 and 12 only differed from the age of 6, and the age of 13 did not differentiate. In general, it was found that the instrument was able to distinguish ages of 6,7 , and 8 , as from the age of 8 differences are not observed with the subsequent ages. In relation to the school year, there was a significant difference from 1st 
to 4 th year, reaching ceiling effect, and the 5th no longer differentiating such groups.

It was also observed moderate correlation between both age and school year with TISD. Regarding age, it was verified correlation of $r=-0.431$ and the school year $r=-0.489$.

Table 3

Post Hoc (Tukey) for Age in TISD total

\begin{tabular}{|c|c|c|c|c|c|c|}
\hline \multirow{2}{*}{ (I) Age } & \multirow{2}{*}{ (J) Age } & \multirow{2}{*}{$\begin{array}{c}\text { Average } \\
\text { difference (I-J) }\end{array}$} & \multirow{2}{*}{$\begin{array}{l}\text { Standard } \\
\text { model }\end{array}$} & \multirow[b]{2}{*}{$p$} & \multicolumn{2}{|c|}{ Confidence interval 95\% } \\
\hline & & & & & Lower limit & Upper limit \\
\hline \multirow{7}{*}{6} & 7 & $27.659^{*}$ & 2.6964 & $\geq 0.001$ & 19.449 & 35.869 \\
\hline & 8 & 35.019 * & 2.6548 & $\geq 0.001$ & 26.935 & 43.102 \\
\hline & 9 & $37.430^{*}$ & 2.5873 & $\geq 0.001$ & 29.552 & 45.308 \\
\hline & 10 & $39.424^{*}$ & 2.6454 & $\geq 0.001$ & 31.370 & 47.479 \\
\hline & 11 & $37.709 *$ & 3.7815 & $\geq 0.001$ & 26.195 & 49.223 \\
\hline & 12 & $35.450 *$ & 6.9868 & $\geq 0.001$ & 14.176 & 56.724 \\
\hline & 13 & 21.617 & 8.4264 & 0.171 & -4.041 & 47.274 \\
\hline \multirow{7}{*}{7} & 6 & $-27.659^{*}$ & 2.6964 & $\geq 0.001$ & -35.869 & -19.449 \\
\hline & 8 & $7.359^{*}$ & 2.3330 & 0.036 & 0.256 & 14.463 \\
\hline & 9 & 9.771 * & 2.2559 & $\geq 0.001$ & 2.902 & 16.640 \\
\hline & 10 & $11.765^{*}$ & 2.3222 & $\geq 0.001$ & 4.694 & 18.836 \\
\hline & 11 & 10.050 & 3.5629 & 0.092 & -0.799 & 20.899 \\
\hline & 12 & 7.791 & 6.8710 & 0.949 & -13.130 & 28.712 \\
\hline & 13 & -6.043 & 8.3306 & 0.996 & -31.408 & 19.323 \\
\hline \multirow{7}{*}{8} & 6 & $-35.019^{*}$ & 2.6548 & $\geq 0.001$ & -43.102 & -26.935 \\
\hline & 7 & $-7.359 *$ & 2.3330 & 0.036 & -14.463 & -0.256 \\
\hline & 9 & 2.412 & 2.2061 & 0.958 & -4.306 & 9.129 \\
\hline & 10 & 4.406 & 2.2739 & 0.526 & -2.518 & 11.330 \\
\hline & 11 & 2.691 & 3.5316 & 0.995 & -8.063 & 13.444 \\
\hline & 12 & 0.431 & 6.8548 & 1.000 & -20.441 & 21.303 \\
\hline & 13 & -13.402 & 8.3172 & 0.743 & -38.727 & 11.923 \\
\hline \multirow{7}{*}{9} & 6 & $-37.430^{*}$ & 2.5873 & $\geq 0.001$ & -45.308 & -29.552 \\
\hline & 7 & $-9.771^{*}$ & 2.2559 & $\geq 0.001$ & -16.640 & -2.902 \\
\hline & 8 & -2.412 & 2.2061 & 0.958 & -9.129 & 4.306 \\
\hline & 10 & 1.994 & 2.1947 & 0.985 & -4.688 & 8.677 \\
\hline & 11 & 0.279 & 3.4811 & 1.000 & -10.321 & 10.879 \\
\hline & 12 & -1.980 & 6.8289 & 1.000 & -22.773 & 18.813 \\
\hline & 13 & -15.814 & 8.2959 & 0.547 & -41.074 & 9.447 \\
\hline \multirow{7}{*}{10} & 6 & $-39.424^{*}$ & 2.6454 & $\geq 0.001$ & -47.479 & -31.370 \\
\hline & 7 & $-11.765^{*}$ & 2.3222 & $\geq 0.001$ & -18.836 & -4.694 \\
\hline & 8 & -4.406 & 2.2739 & 0.526 & -11.330 & 2.518 \\
\hline & 9 & -1.994 & 2.1947 & 0.985 & -8.677 & 4.688 \\
\hline & 11 & -1.715 & 3.5245 & 1.000 & -12.447 & 9.016 \\
\hline & 12 & -3.974 & 6.8511 & 0.999 & -24.835 & 16.886 \\
\hline & 13 & -17.808 & 8.3142 & 0.390 & -43.123 & 7.508 \\
\hline \multirow{7}{*}{11} & 6 & $-37.709 *$ & 3.7815 & $\geq 0.001$ & -49.223 & -26.195 \\
\hline & 7 & -10.050 & 3.5629 & 0.092 & -20.899 & 0.799 \\
\hline & 8 & -2.691 & 3.5316 & 0.995 & -13.444 & 8.063 \\
\hline & 9 & -0.279 & 3.4811 & 1.000 & -10.879 & 10.321 \\
\hline & 10 & 1.715 & 3.5245 & 1.000 & -9.016 & 12.447 \\
\hline & 12 & -2.259 & 7.3647 & 1.000 & -24.684 & 20.165 \\
\hline & 13 & -16.093 & 8.7423 & 0.592 & -42.712 & 10.527 \\
\hline
\end{tabular}


Table 3 (continuation)

Post Hoc (Tukey) for Age in TISD total

\begin{tabular}{|c|c|c|c|c|c|c|}
\hline \multirow{2}{*}{ (I) Age } & \multirow{2}{*}{ (J) Age } & \multirow{2}{*}{$\begin{array}{c}\text { Average } \\
\text { difference (I-J) }\end{array}$} & \multirow{2}{*}{$\begin{array}{l}\text { Standard } \\
\text { model }\end{array}$} & \multirow{2}{*}{$p$} & \multicolumn{2}{|c|}{ Confidence interval 95\% } \\
\hline & & & & & Lower limit & Upper limit \\
\hline \multirow{7}{*}{12} & 6 & $-35.450^{*}$ & 6.9868 & $\geq 0.001$ & -56.724 & -14.176 \\
\hline & 7 & -7.791 & 6.8710 & 0.949 & -28.712 & 13.130 \\
\hline & 8 & -0.431 & 6.8548 & 1.000 & -21.303 & 20.441 \\
\hline & 9 & 1.980 & 6.8289 & 1.000 & -18.813 & 22.773 \\
\hline & 10 & 3.974 & 6.8511 & 0.999 & -16.886 & 24.835 \\
\hline & 11 & 2.259 & 7.3647 & 1.000 & -20.165 & 24.684 \\
\hline & 13 & -13.833 & 10.5330 & 0.894 & -45.905 & 18.238 \\
\hline \multirow{7}{*}{13} & 6 & -21.617 & 8.4264 & 0.171 & -47.274 & 4.041 \\
\hline & 7 & 6.043 & 8.3306 & 0.996 & -19.323 & 31.408 \\
\hline & 8 & 13.402 & 8.3172 & 0.743 & -11.923 & 38.727 \\
\hline & 9 & 15.814 & 8.2959 & 0.547 & -9.447 & 41.074 \\
\hline & 10 & 17.808 & 8.3142 & 0.390 & -7.508 & 43.123 \\
\hline & 11 & 16.093 & 8.7423 & 0.592 & -10.527 & 42.712 \\
\hline & 12 & 13.833 & 10.5330 & 0.894 & -18.238 & 45.905 \\
\hline
\end{tabular}

Note. ${ }^{*}$ The average difference is significant at 0.05 level

Table 4

Post-Hoc (Tukey) for School Year in TISD total

\begin{tabular}{|c|c|c|c|c|c|c|}
\hline \multirow{2}{*}{ (I) Education } & \multirow{2}{*}{ (J) Education } & \multirow{2}{*}{$\begin{array}{c}\text { Average } \\
\text { difference (IJ) }\end{array}$} & \multirow{2}{*}{$\begin{array}{c}\text { Standard } \\
\text { model }\end{array}$} & \multirow{2}{*}{ Sig. } & \multicolumn{2}{|c|}{ Confidence interval $95 \%$} \\
\hline & & & & & Lower limit & Upper limit \\
\hline \multirow{4}{*}{1} & 2 & $25.076^{*}$ & 2.4338 & $\geq 0.001$ & 18.411 & 31.741 \\
\hline & 3 & $25.236^{*}$ & 2.2977 & $\geq 0.001$ & 18.944 & 31.529 \\
\hline & 4 & $32.590^{*}$ & 2.3412 & $\geq 0.001$ & 26.179 & 39.002 \\
\hline & 5 & $34.031 *$ & 2.3657 & $\geq 0.001$ & 27.552 & 40.509 \\
\hline \multirow{4}{*}{2} & 1 & $-25.076^{*}$ & 2.4338 & $\geq 0.001$ & -31.741 & -18.411 \\
\hline & 3 & 0.160 & 2.2543 & 1.000 & -6.013 & 6.334 \\
\hline & 4 & $7.514^{*}$ & 2.2986 & 0.010 & 1.219 & 13.809 \\
\hline & 5 & $8.955^{*}$ & 2.3236 & 0.001 & 2.591 & 15.318 \\
\hline \multirow{4}{*}{3} & 1 & $-25.236^{*}$ & 2.2977 & $\geq 0.001$ & -31.529 & -18.944 \\
\hline & 2 & -0.160 & 2.2543 & 1.000 & -6.334 & 6.013 \\
\hline & 4 & $7.354^{*}$ & 2.1539 & 0.006 & 1.455 & 13.253 \\
\hline & 5 & $8.794^{*}$ & 2.1805 & 0.001 & 2.822 & 14.766 \\
\hline \multirow{4}{*}{4} & 1 & $-32.590 *$ & 2.3412 & $\geq 0.001$ & -39.002 & -26.179 \\
\hline & 2 & $-7.514^{*}$ & 2.2986 & 0.010 & -13.809 & -1.219 \\
\hline & 3 & $-7.354^{*}$ & 2.1539 & 0.006 & -13.253 & -1.455 \\
\hline & 5 & 1.440 & 2.2263 & 0.967 & -4.657 & 7.537 \\
\hline \multirow{4}{*}{5} & 1 & $-34.031^{*}$ & 2.3657 & $\geq 0.001$ & -40.509 & -27.552 \\
\hline & 2 & $-8.955^{*}$ & 2.3236 & 0.001 & -15.318 & -2.591 \\
\hline & 3 & $-8.794^{*}$ & 2.1805 & 0.001 & -14.766 & -2.822 \\
\hline & 4 & -1.440 & 2.2263 & 0.967 & -7.537 & 4.657 \\
\hline
\end{tabular}

Note. ${ }^{*}$ The average difference is significant at 0.05 level 


\section{Discussion}

This study aimed to verify the effects of variables that are considered to mediate the development of cognitive-linguistic skills in the performance of TISD such as age, school year (and type of school, public or private) and gender. Specifically from the analysis of the first two, we sought to investigate evidence of validity of the instrument based on external variables. At first, it was observed that the results obtained showed the effect of age on the test. The performance of the children improved with the increase of this variable, with a significant difference between children of ages six, seven, and eight. It was also observed effect of schooling, with a significant difference from the 1 st to the 4th school year. These data indicate that these developmental variables influenced the test.

On instruments already validated in Brazil, which were used as models for the construction of some TISD subtests (both its theoretical basis as the activities themselves), this profile change according to age and school development can also be found. For example, in "Bender-Gestalt test," which was the basis for the construction of motor skills subtest, the authors Pinto and Noronha (2015) found that effects were observed in the age variable sample. Pawlowski, Fonseca, Salles, Parente, and Bandeira (2008) demonstrated that the school year has significantly influenced the test scores of "Neuropsychological Assessment Brief (Avaliação Neuropisicológica Breve) - NEUPSILIN". This instrument consisted of some subtests similar to that compose TISD, assessing, for example, short-term memory, rapid naming, arithmetic skills, motor skills and their own written language. In more specific tests for language evaluation, such as "Test of Phonological Awareness by Choosing Pictures (Prova de Consciência Fonológica por Escolha de Figuras)" and TDE, which likewise has its similarities to TISD, school year effects were also found (Capovilla, Marcilio, \& Capovilla, 2004; Stein, 1994).

Despite the improved performance of the test from ages of six to 10 thereafter, there was an increasing worsening on ages 11 to 13 . It is possible that participants with these ages presented learning difficulties and school year repetition, as the students selected for the sample were enrolled from first to fifth year, the variation of expected age was six to ten years. Probably these characteristics negatively affect TISD performance in this case.

Interestingly Almeida, Guisendé, Lemos, and Primi (2008) point out that the age factor has effect on the score tests with developmental profile and consequently its results, but this effect is not linear, namely irregular. These authors indicate that education is used in the grading of children and adolescents because the performances are presented more uniform in accordance with the development of this variable, with more robust positive direct relationship. Interestingly, TISD results showed exactly that profile. When analyzed the age, there was an increase not expected in the score from age 11, unlike observed in school years, there has been a subsequent decrease and also the correlation between TISD and school years was a little stronger.

It was also observed that there was no statistically significant difference between the ages from eight years and also the 4 th to the 5 th school year. This finding can be explained by the activity becoming too easy for ages and more advanced school years, which often provides the best performance among these groups and consequently no differentiation between their results. This finding corresponds to the so-called "ceiling effect" (Ho $\&$ Yu, 2015). In this case, TISD was effective in identifying age up to the age of eight and until the 4th year, assuming ceiling effect from these developmental stages.

Regarding the type of school, the results indicated a better performance of private schools compared to public. The main variable to be highlighted when there is this kind of research is socioeconomic, since access to the private school is strongly associated with higher household incomes (Nunes \& Perosa, 2017). According to literature review conducted by Hackman and Farah (2009), it was found that this variable has a significant impact on the linguistic performance, and found that the higher the social status, developments are best observed. In the same study, the authors found evidence of significant and frequent effects on the development of skills related specifically to the written language, such as syntactic and phonological awareness.

Thus, as to gender, the results showed no significant effect of this variable in TISD, confirming findings of research on the non-existence of differences in cognitive verbal measures (Hyde, 2014; Wechsler et al., 2014; Zell et al., 2015). However, it raises the hypothesis that TISD is not be able to identify these differences because it is a screening tool, with many basic tasks.

But this variable deserves to be further investigated in a larger sample of the instrument or in specific cases of their use, as in other studies, such as the review study conducted by Wallentin (2009), were checked worst male performance in autism and DD, as well as children in general. Also in later study conducted by Lundberg et al. (2012), which were evaluated over 2000 six-year-oldchildren, on the phonological awareness. The authors also found a significant difference in this ability between the genders, with best female performance.

Therefore, the effects on TISD of the variables age and school year (as well as the type of school) were checked, but not gender. Thus, in parts, the hypothesis in this study was confirmed, it was expected to find the effects of all these variables. However it was found evidence of validity based on relations with external variables according to these developmental variables.

On the other hand, the limitations of the present study mainly involved the distribution of the sample according to the regions. The investigation occured 
largely on children and adolescents from the Southeast. It is suggested that in future studies this variable is better controlled, as well as its effects on test performance are investigated.

In any case, It is expected that other evidence of validity of the TISD will be verified in the future, for example, through analysis of its internal structure, via confirmatory factorial analysis or structural equation modeling. And its reliability is also found, for example, through analysis of its internal consistency.
Among the scientific contributions that this study has entailed, one can point in a certain way to the finding that cognitive-linguistic skills, routinely mentioned in the literature as linked to development, presented empirical data which further strengthen this finding. Consequently, the social contribution that can be highlighted refers to TISD's validation process itself, that with this study strengthens its continuity and for the future to be made available for professional use, which lacks an instrument for evaluating the DD construct.

\section{References}

Almeida, L. S., Lemos, G., Guisande, M. A., \& Primi, R. (2008). Inteligência, escolarização e idade: normas por idade ou série escolar? Avaliação Psicológica, 7(2), 117-125. Recuperado de http://pepsic.bvsalud.org/scielo.php?script=sci_arttext\&pid=S1677-04712008000200002\&ln $\mathrm{g}=\mathrm{pt} \& \mathrm{t} \operatorname{lng}=\mathrm{pt}$

Alves, M. N., Lima, R. F., Alves, R. J. R., Salgado-Azoni C. A., Nakano T. C., \& Ciasca S. M. (2013) Estudo piloto de validação do teste de identificação de sinais de dislexia (TISD). Estudos Interdisciplinares em Psicologia, 4(2), 217-239. doi: 10.5433/2236-6407.2013v4n2p217

Alves, R. J. R., Lima, R.F., Salgado-Azoni, C. A., Carvalho, M. C., \& Ciasca, S. M. (2015). Teste para Identificação de Sinais de Dislexia: processo de construção. Estudos de Psicologia (Campinas), 32(3), 383-393. doi: 10.1590/0103-166X2015000300004

American Educational Research Association (AERA), American Psychological Association (APA), \& National Council on Measurement in Education (NCME) (2014). Standards for educational and psychological testing. Washington, DC: American Educational Research Association.

American Psychological Association (APA) (2013). Diagnostic and statistical manual of mental disorders: DSM-V. Washington, DC: American Psychiatric Association.

Capellini S. A., \& Smythe, I. (2008). Protocolo de avaliação de habilidades cognitivo-linguísticas: livro do profissional e do professor. Marília: Fundepe.

Capellini, S. A., Sampaio, M. N., Matsuzawa, M. T., Oliveira, A. M., Fadini, C. C., \& Martins, M. A. (2009). Protocolo de identificação precoce dos problemas de leitura: estudo preliminar com escolares de $1^{\circ}$ ano escolar. Psicopedagogia, 26(81), 367-375. Recuperado de http://pepsic.bvsalud.org/scielo.php?script=sci_arttext\&pid $=$ S0103-84862009000300004\&lng=pt\&tlng=pt

Capovilla, F. C., Marcilio, L. F., \& Capovilla, A. G. (2004). Prova de consciência fonológica por escolha de figuras (PCFF) para avaliação coletiva em sala de aula e de crianças com paralisia cerebral. In L. E. L. Ribeiro do Valle, \& F. C. Capovilla (Orgs.), Temas multidisciplinares de neuropsicologia e aprendizagem (pp. 693-715). São Paulo: Tecmedd.

Coates, J. (2015). Women, men and language: A sociolinguistic account of gender differences in language. New York, NY: Routledge.

Corder, G. W., \& Foreman, D. I. (2014). Nonparametric statistics: A step-by-step approach. New Jersey: John Wiley \& Sons.

Cox, E. A. (2002). An evaluation of the psychometric properties of the test of dyslexia e dysgraphia. Tese de Doutorado. University of Tennessee: EUA.

Cronk, B. C. (2017). How to use SPSS ${ }^{\oplus}:$ A step-by-step guide to analysis and interpretation. New York, NY: Routledge.

Fawcett, A., Lee, R., \& Nicolson, R. (2014). Sustained benefits of a multi-skill intervention for preschool children at risk of literacy difficulties. Asian Pacific Journal of Developmental differences, 1(1), 62-68. doi: 10.3850/S2345734114000064

Flores-Mendoza, C., Widaman, K.F., Rindermann, H., Primi, R., Mansur-Alves, M. \& Pena, C.C. (2013). Cognitive sex differences in reasoning tasks: Evidence from Brazilian samples of educational settings. Intelligence, 41(1), 70-84. doi: 10.1016/j.intell.2012.11.002

Corder, G. W., \& Foreman, D. I. (2014). Nonparametric statistics: A step-by-step approach. John Wiley \& Sons.

Germano, G. D., César, A. B. P. de C., \& Capellini, S. A. (2017). Screening Protocol for Early Identification of Brazilian Children at Risk for Dyslexia. Frontiers in Psychology. 8(1763), 1-13. doi: 10.3389/fpsyg.2017.01763

Goldbeck, L., Daseking, M., Hellwig-Brida, S., Waldman, H.C. \& Petermann, F. (2010). Sex differences on the German Wechsler Intelligence Test for Children (WISC-IV). Journal of Individual Differences, 31(1), 22-28. doi: 10.1027/1614-0001/a000003

Hackman, D. A., \& Farah, M. J. (2009). Socioeconomic status and the developing brain. Trends in Cognitive Sciences, 13(2), 65-73. doi: 10.1016/j.tics.2008.11.003

Ho, A. D., \& Yu, C. C. (2015). Descriptive statistics for modern test score distributions: Skewness, kurtosis, discreteness, and ceiling effects. Educational and Psychological Measurement, 75(3), 365-388. doi: 10.1177/0013164414548576

Hyde, J. S. (2014). Gender similarities and differences. Annual Review of Psychology, 65,373-398. doi: 10.1146/annurev-psych-010213-115057

Lundberg, I., Larsman, P., \& Strid, A. (2012). Development of phonological awareness during the preschool year: The influence of gender and socio-economic status. Reading and Writing, 25(2), 305-320. doi: 10.1007/s11145-010-9269-4

Mertler, C. A., \& Reinhart, R. V. (2016). Advanced and multivariate statistical methods: Practical application and interpretation. New York, NY: Routledge.

Nunes, V. H., \& Perosa, G. B. (2017). Dental decay in 5-year-old children: sociodemographic factors, locus of control and parental attitudes. Ciencia E Saude Coletiva, 22(1), 191-200. doi: 10.1590/1413-81232017221.13582015

Organização Mundial de Saúde (OMS). (1993). CID-10: Classificação de transtornos mentais e de comportamento: descrições clínicas e diretrizes diagnósticas. Porto Alegre: Artes Médicas.

Pawlowski, J., Fonseca, R. P., Salles, J. F. de, Parente, M. A. de M. P., \& Bandeira, D. R. (2008). Evidências de validade do Instrumento de Avaliação Neuropsicológica Breve Neupsilin. Arquivos Brasileiros de Psicologia, 60(2), 101-116. Recuperado de http://pepsic.bvsalud.org/ scielo.php? script $=$ sci arttext\&pid $=$ S1809-52672008000200011\&lng $=$ pt\&tlng $=$ pt 
Pinto, L. P., \& Noronha, A. P. P. (2015). Maturidade perceptomotora e sua relação com idade e variáveis contextuais: um estudo com o Bender (B-SPG). Encontro: Revista de Psicologia, 13(19), 145-155. Recuperado de http://www.pgsskroton.com.br/seer/index.php/renc/ article/view/2522

Smythe, I., \& Everatt, J. (2000). International dyslexia test (IDT). University of Surrey.

Stein, L.M. (1994). Teste de desempenho escolar. São Paulo: Casa do Psicólogo.

Voyer, D., \& Voyer, S. D. (2014). Gender differences in scholastic achievement: A meta-analysis. Psychological Bulletin, 140(4), 1174. doi: 10.1037/a0036620

Wallentin, M. (2009). Putative sex differences in verbal abilities and language cortex: a critical review. Brain E Language, 108(3), 175-83. doi: 10.1016/j.bandl.2008.07.001

Wechsler, S. M., Nakano, T. C., Domingues, S. F. S., Rosa, H. R., Silva, R. B. F., Silva Filho, J. H., \& Minervino, C. A. S. M. (2014). Gender diferences on tests of crystallized intelligence. European Journal of Education and Psychology, 7(1), 57-70. Recuperado de http://www. redalyc.org/html/1293/129330657005/

Zell, E., Krizan, Z., \& Teeter, S. R. (2015). Evaluating gender similarities and differences using metasynthesis. American Psychologist, 70(1), 10. doi: $10.1037 / \mathrm{a} 0038208$

\section{Sobre os autores}

Rauni Jandé Roama-Alves is a Psychologist, PhD in Psychology from the Catholic University of Campinas. Psychology program Assistant professor at the Federal University of Mato Grosso.

Sofia Pellisson is a Psychologist, with specialization in Neuropsychology Applied to Child Neurology at the State University of Campinas.

Tatiana de Cassia Nakano is a Psychologist, PhD in Psychology from the Catholic University of Campinas. Stricto sensu postgraduate program lecturer in psychology at the Catholic University of Campinas.

Cintia Alves Salgado-Azoni is a speech-language therapist, PhD in Medical Sciences from the State University of Campinas. Speech, language and hearing sciences program assistant professor at the Federal University of Rio Grande do Norte.

Tatiane Lebre Dias is a Psychologist, PhD in Psychology from the Federal University of Espirito Santo. Psychology program Assistant professor at the Federal University of Mato Grosso.

Sylvia Maria Ciasca is a Psychologist, PhD in Neuroscience from the University of Campinas. Professor of Child Neurology at the School of Medical Sciences / UNICAMP. 